\title{
RATIONALIZATION OF MATERIAL FLOW IN PRODUCTION OF SEMITRAILER FRAME FOR AUTOMOTIVE INDUSTRY
}

\author{
Dominika Lehocká, Ivo Hlavatý, Sergej Hloch
}

Professional paper

The core idea of the paper is a value stream mapping with identification of waste sources, and drawbacks which help to uncover hidden reserves of production. The analysis covers the current state of individual processes within the production line. After determination of the present drawbacks the plan of rationalization was created in which the combination of elements of lean production was used. The proposed solutions could be used when establishing the principles of lean production at particular sections of the assembly line within the whole plant. In case that proposed solution cannot be put into practice it can be used as a blueprint for other types of improvement respectively decreasing of waste and drawbacks.

Keywords: increasing of value; semitrailer frame; value stream mapping; waste management; welding

Racionalizacija toka materijala u proizvodnji polu-okvira za automobilsku industriju

Stručni članak

Osnovna ideja rada je prikaz toka vrijednosti uz identifikaciju izvora troškova i nedostataka, koji će pomoći da se razotkriju skrivene pričuve u proizvodnji. Analiza obuhvaća postojeće stanje u pojedinačnim postupcima na proizvodnoj traci. Nakon prepoznavanja postojećih nedostataka napravljen je plan racionalizacije u kojemu je rabljena kombinacija elemenata lean proizvodnje. Predložena bi se rješenja mogla primijeniti kad se primijene principi lean proizvodnje na pojedinim dijelovima montažne trake u cijelom pogonu. U slučaju da se predloženo rješenje ne može primijeniti u praksi može se koristiti kao model za druge vrste poboljšanja kao što su smanjenje otpada i nedostataka.

Ključne riječi: poluokvir; povećanje vrijednosti; prikaz toka vrijednosti; upravljanje otpadom; zavarivanje

\section{Introduction}

At present the frequent reason for companies' cessation is ignorance of possible utilization of hidden reserves and incapability of wasting sources detecting on diverse levels in a company. The aforementioned is possible to be prevented by means of application by lean production concepts. Lean concept originated after World War II in Japan and underwent a significant worldwide application at the beginning of the fifties after a book "Machine that Changed the World" by author Womack et al. [1]. Many authors such as Košturiak et al. [2] and Rother et al. [3] presented a model that helped the Japanese industry (Toyota) achieve rebirth and take leadership position in production compared to the American car industry.

Implementation of lean philosophy to production or service systems that do business in more dynamic surroundings of today, requires a detailed analysis of time characteristics of the system such as: production tact time, lead time, delivery time and others. One of the significant problems facing the production industry is timely product or service delivery. In order to better respond to this problem, Božičkovič et al. [4] and Arsovski et al. [5] suggested integration of strategic and tactical decisions and enabling synchronisation and modification of production plans on the production level as soon as possible. In order to introduce synchronization of the process it is necessary to have a detailed insight into process flows and their overlap. Description and detailed representation of flows in the production system can be presented by flow maps, i. e. VSM. First publication, the one where Value Stream Mapping (hereinafter referred to as VSM) was described, was "Learning to See", where authors Rother et al. [3] defined VSM. With reference to the VSM method, described by authors Rother et al. [3] incurred other publications focused on implementation of value stream management in companies. Authors, who describe specifically examples of implementation of VSM in companies, for example, were Abdulmalek et al. [6], Chen et al. [7], Gjeldum et al. [8], Harris et al. [9], Kysel' et al. [10] and Smalley et al. [11]

Even today there are many companies whose production or service systems are still designed according to the traditional approach and where changes are very difficult to introduce [4]. The practice proves that in a certain lapse of time and by the appropriate control and improvement of processes far better results are achieved, which are reflected mainly in finances saving, production simplification, discrepancies reduction, growing production, increase of effectiveness, shorter continuous production periods, and less intensive loading of workers [2]. The basic rests on the most effective reaching out for maximum available sources at particular place and time by simple means and logical proposal of changes.

\section{Methodology}

\subsection{Solved issue}

As in any other company so even in the TOMARK Ltd drawbacks occur that need to be permanently improved. As the company focuses especially on machining, forming, cutting of metallurgical materials and production of welded structures and components for automotive industry [12] the production ideas of lean philosophy should be applied right in this sphere.

Core Activities of the Company [13]:

Frame production in which steel parts are processed mechanically and the results are large size components of semitrailers for towing vehicles; 
Other mechanical production serving as utilization of vacant capacities of operations for material cutting, production, and machining of welded structures;

Production of aviation technique - the ultra-light planes of the type SD - 4 Viper are produced.

This should be a monitoring event of the activities on a selected workplace in case of which hidden wasting forms were detected by means of the VSM method related to one of the basic company activities frame production.

\subsection{Value Stream Management (VSM)}

Elimination of waste follows correct identification and measuring. The basic method is Value Stream Management the core of which rests on value stream mapping with value stream consisting of all processes that occur along the track from material to a final product [2].

VSM helps to collect inevitable information on critical spots and drawbacks in case of which the highest loss of money, time, and productivity occurs and it indicates the areas of necessary improvement and allows planning and forming the changes for the future state [2]. The advantage of the method rests on its simplicity and rate - in a period of short time and by using a sheet of paper, a pencil, and an eraser it is possible to acquire a rather valuable point of view regarding the wasting in a company [2]. Fundamental Steps of VSM are shown in Fig. 1.

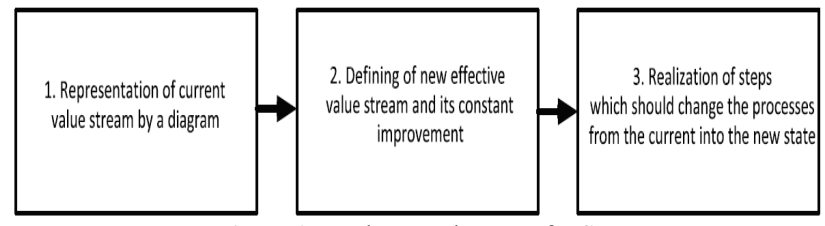

Figure1 Fundamental steps of VSM

Correct evaluation and comparison of current and newly proposed state of the process by the VSM method requires calculation by the key metrics as follows [10, 13]:

\section{Clock period $[10,13]$}

Clock period $=\frac{\text { shift rate } \times(\text { length of shift }- \text { breaktime })}{\text { daily requirement of final products }}$

Continuous production period- overall period from material input into a storage place to output of a final product from the storage place at dispatch $[10,13]$.

$C P P=\sum_{i=1}^{n} V A_{i}+\sum_{i=1}^{n} V E_{i}+\sum_{i=1}^{n} N V A_{i}$.

Index of added value - specifies the added value of a product in percentage from Continuous Production Period (hereinafter referred to as $C P P$ ). The reversed value of index determines percentage of wasting. In case of mapping of the processes the effort is made to increase the value of the index which is possible by shortening of $C P P[10,13]$.
$\% V A=\frac{\sum_{i=1}^{n} V A_{i}}{C P P} \times 100 \%$.

Stock turn - defines how many times it is possible to "turn" daily demand of a customer with respect to real CPP $[10,13]$.

$S T=\frac{A D C}{D D C \times C P P}$

Number of procedural steps- sum of all procedural steps taken in case of value stream $[10,13]$.

$$
N P S=\sum_{i=1}^{n} P S V A_{i}+\sum_{i=1}^{n} P S V E_{i}+\sum_{i=1}^{n} P S V N A_{i}
$$

\section{Analysis of current situation in the company TOMARK Ltd.}

At the selected workplace the completion and the components welding of automobile semitrailer frame prior to shift to dispatch are performed. The production process of the entire frame is complicated and consists of several partial operations, (for example Figs. 7, 8, 11) therefore production monitoring would be demanding and ineffective. As the most suitable solution for the aforementioned was division of the entire process into partial sections. The production section at the monitored workplace was selected with respect to its robotization. In the process two robotized workplaces are utilized (hereinafter referred to as RZP-1 and RZP-2) for welding of 2 supporting parts of a frame - a peen (RZP-1) and a deck (RZP-2).A type of semitrailer frame was selected with respect to export frequency and as the customer's requirement regarding the frame is received on daily basis such solution was approached. The map of value stream of current state at the workplace is shown in Fig. 2.

The production process presented in Fig. 2 shows drawbacks which caused deceleration and overcharging of the production. The company is aware of the drawbacks and thus it endeavours to implement gradually the ideas of lean thinking into production. The conditions in the company and assortment of the products prevent abrupt changes introduction and consequent change of the entire production system. With respect to the aforementioned the most appropriate idea rests on gradual improvement of certain selected production parts.

\subsection{Problems causing the wasting}

As the main drawbacks of the selected production section (Fig. 2), the following sources of waste can be defined: waiting for material, waiting for manipulation means (in this case it is a portal crane), formation and waiting for production in progress, lack of space at workplace and complicated material flow through the individual production operations. Waiting occurs in various forms and at diverse places it appears to be the most frequent wasting means. Unnecessary spending of 
costs related to waiting is profitable for the company only in exceptional cases. Despite the aforementioned the drawback occurs rather often and along with useless transfer of production in progress, complicated schedule of material flow and other related drawbacks, it consumes quite a big amount of finances and prevents meeting the main objective in the company - earning of money. Potentials of possible improvements in the process are shown in Fig. 3 presenting the places with occurring drawbacks and with particular proposal of their solution.

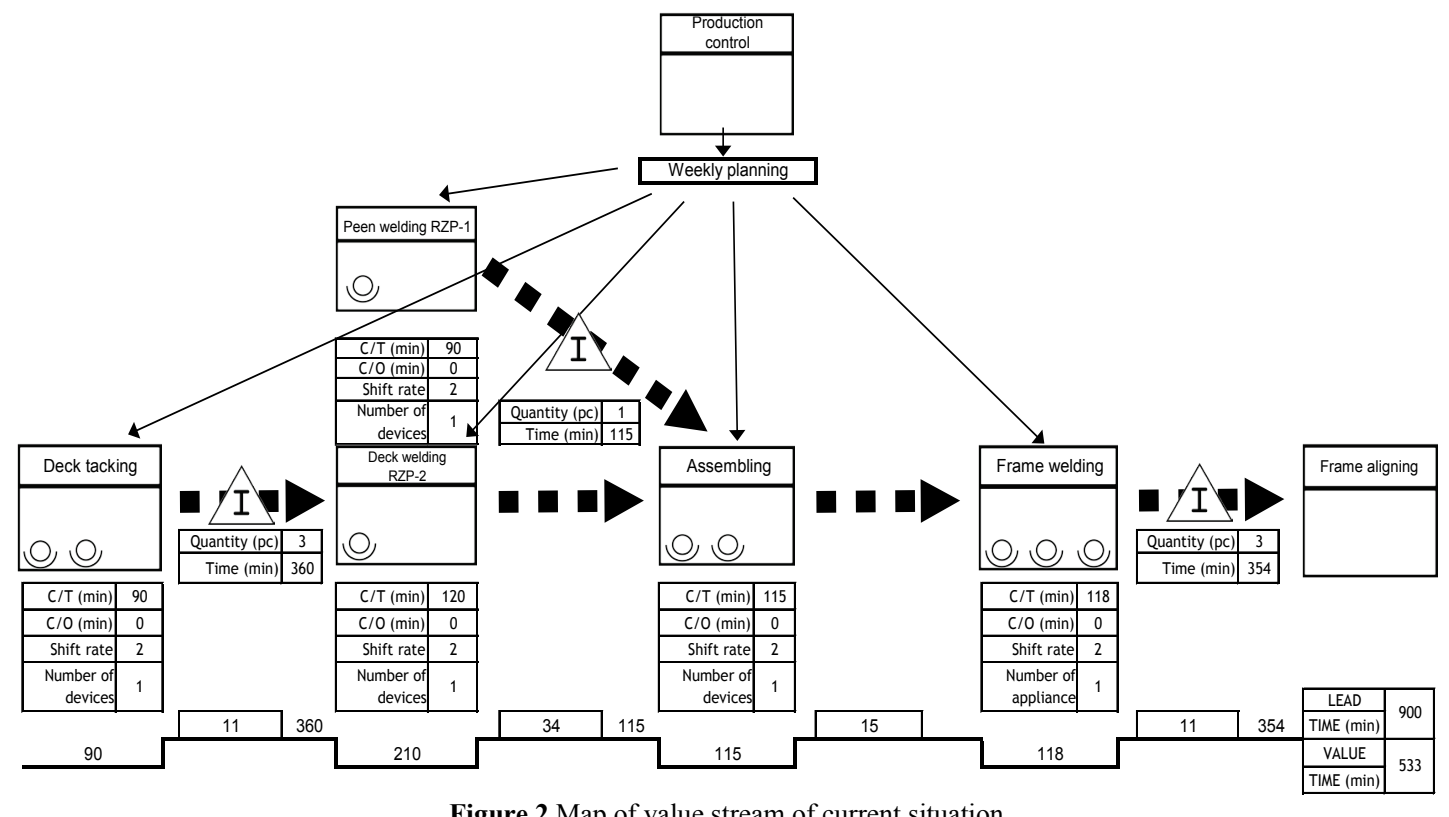

Figure 2 Map of value stream of current situation

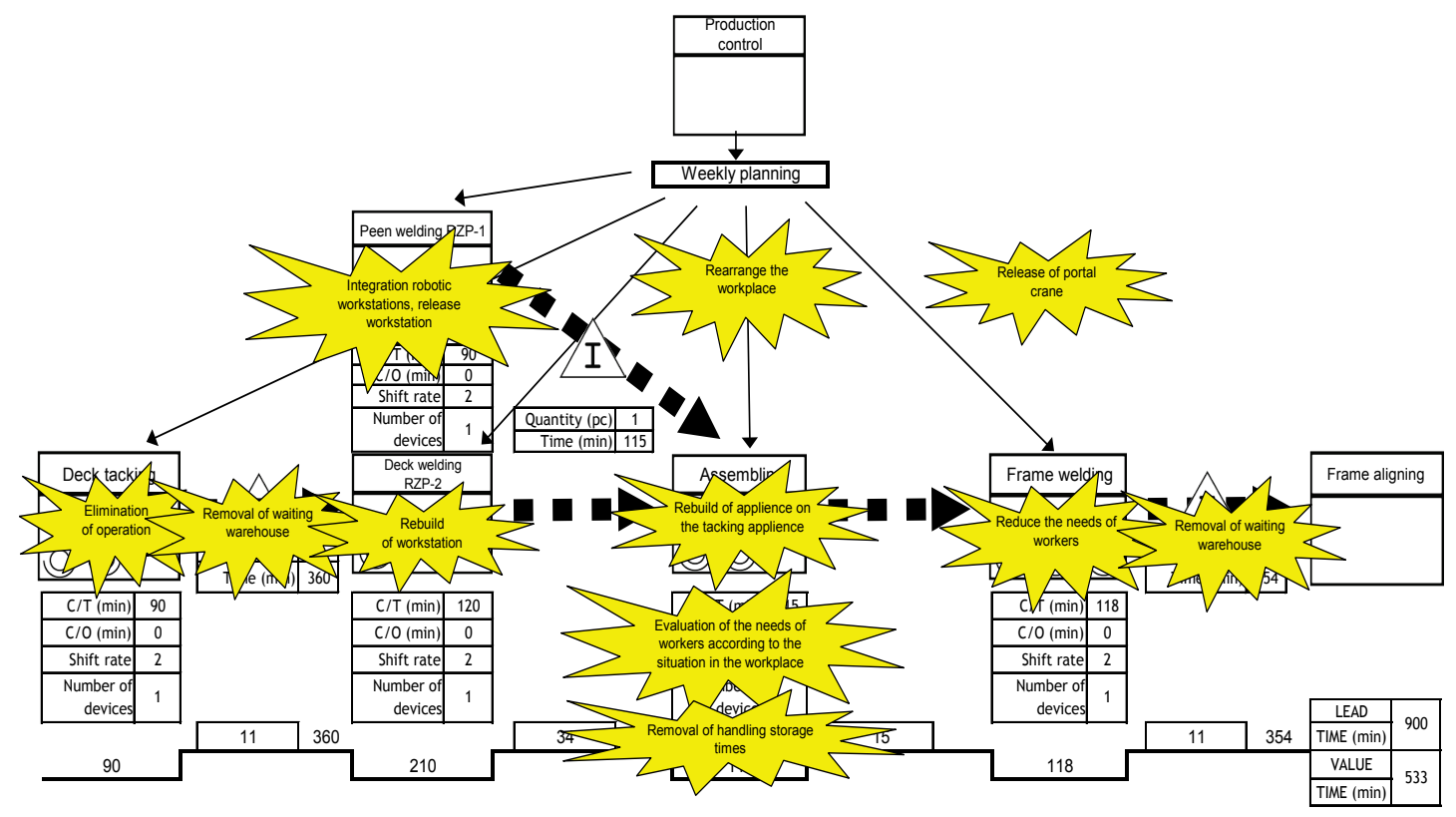

Figure 3 Potentials of changes in current map of value stream

Ineffective waiting for the material is under the conditions of the company caused by waiting for the manipulation means. In the process a portal crane with the lifting weight up to $5 \mathrm{t}$ is necessary to be applied due to the weight of welded parts. The problem arises when the crane is needed for the parts transfer at several places at a time. In this case inadequate waiting occurs along with the production decelerating. It is also caused by the fact that only a single portal crane is available for the monitored workplace. However, the possibility of other portal crane appeared from a nearby workplace with sufficient weight inevitable for transfer of heavy welded structures, but the utilization of which is ineffective. A crane is used for transferring parts with far lower weight than it was designed for (crane weight is of $10 \mathrm{t}$, weight of parts the crane manipulates with is of $500 \div 600 \mathrm{~kg}$ ).

In this case the most effective appears to be replacement of activities of the aforementioned crane by two rotary column manipulators at workplaces offering such possibility. By means of taking this step a portal crane with lifting weight $10 \mathrm{t}$ would be thus disengaged to perform more demanding activities as to weight. The change would result in more optimal utilization of available capacity of a crane and in shortening of time not adding the value to a final product. 
Rotary cranes were placed at the columns to allow transfer of such equipment in reorganization case of devices in operation. The purchase was performed with a Slovak supplier with which the company has good business relationship. In global terms the purchase from a Slovak supplier would mean the support of domestic producer that could even enhance the Slovak economy, though to insignificant extent.

\subsection{Fusion of operations}

The biggest problem of the workplace is rather complicated material flow and performance of unnecessary transfers of semi-finished components from production to storage places $[16 \div 18]$. At present three devices, applied in different types of activity and two separated robotized centres for welding of the supporting frame parts (hereinafter referred to as RZP-1 and RZP-2), are utilized at the workplace. By means of inappropriate production clocking the storage places of production in progress are generated. By underutilization of the influence of a single manipulator only, the time is lost while waiting for the crane. The process bottleneck is robotized welding of a frame part - deck at RZP-2 (Fig. $7)$. The operation has the longest period of a cycle (120 minutes) and the production is fitted to it. In such event as is the case of a robot, the activity acceleration by the increase of workers number at the workplace is impossible. Welding at RZP-2 (Fig. 7) is performed by means of two welding units marked as Almega AX-V4L AP by the company OTC - Daihen (Fig. 4). It is important to mention that the robotized welding is required by a customer and advantage of such welding rests on the quality of realized weld joints followed by complaint frequency of discrepancies.

Not only does the complicated material flow causes enormous time and financial loss in the company, but it increases the threat to work safety as well. Suitable reconstruction of the workplace represents the simplest problem solution. Since it is the case of welded structures with high weight the transfer of individual parts is rather dangerous and demanding as to manipulation. Probability of injury occurrence increases also with transfer of welded structures to storage places of production in progress. In such case the improvement proposal would consist of operations fusion (Figs. 5, 6) and extension of the robotized centre RZP-2 (Fig. 7). The first step would be fusion of two operations (Fig. 5) the activity of which would be taken at reconstructed device (currently utilized for a frame completion). Further and the most significant step to take would be the already mentioned extension of RZP-2 (Fig. 7) by constructing and attaching a part of the robotized centre to the present one by means of which fusion of operations shown in Fig. 6 would be achieved. At this place a complete welding of the entire pre-tacked structure with both supporting frame parts (a peen+ a deck) would be performed. To the new RZP the other two welding units of the type Almega AX-V4L AP (Fig. 4) would be added and the entire tacked frame would be consequently welded by four welding units of the aforementioned type.
After realization of submitted proposals a new map of value stream with new production lay-out is possible to be defined (Fig. 8)

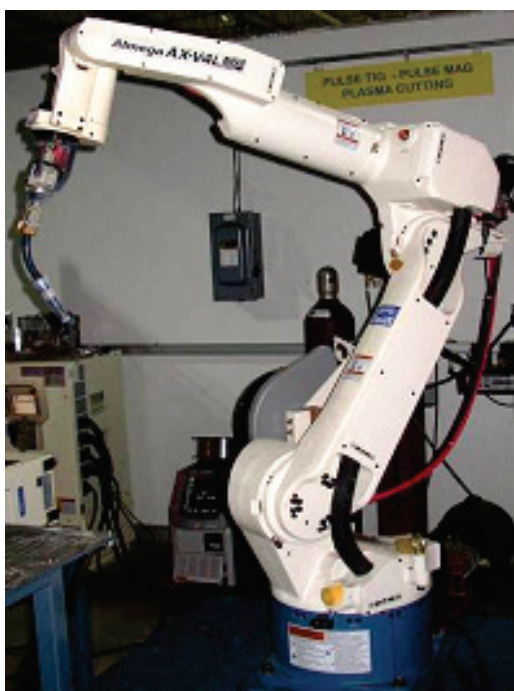

Figure 4 Robot designed for a deck welding Almega AX-V4L AP [15]

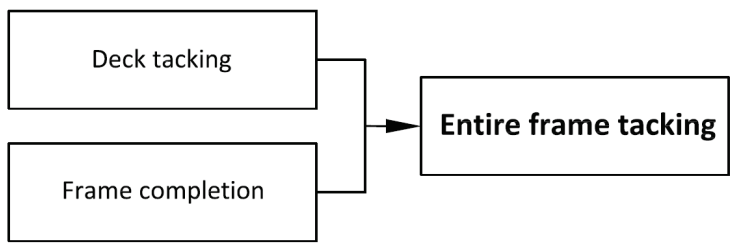

Figure 5 Fusion of operations at devices

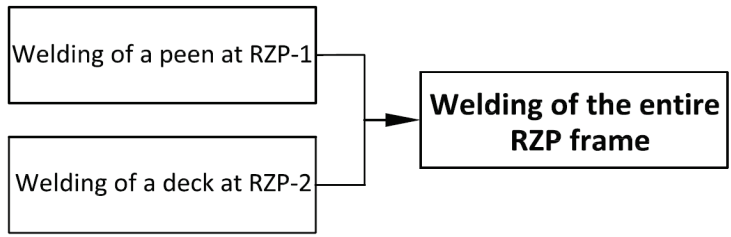

Figure 6 Fusion of activities at RZP

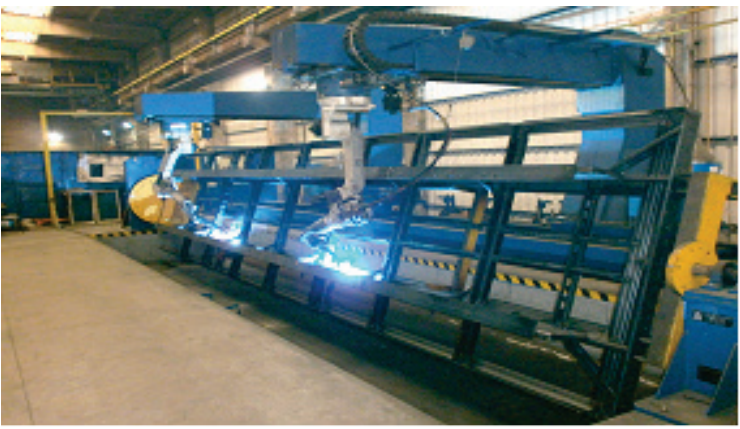

Figure 7 RZP-2 - deck welding

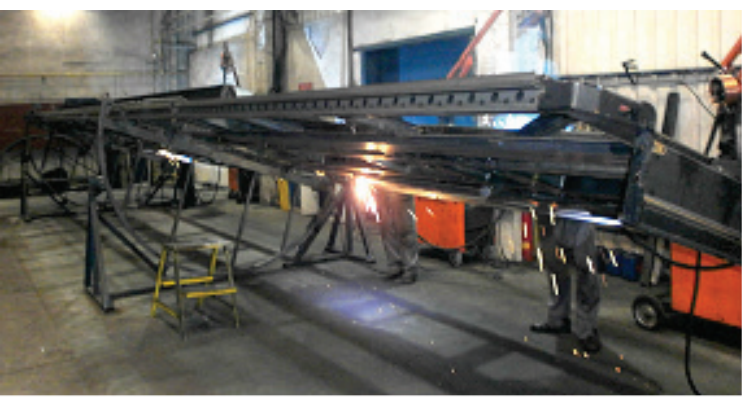

Figure 8 Manual frame welding 


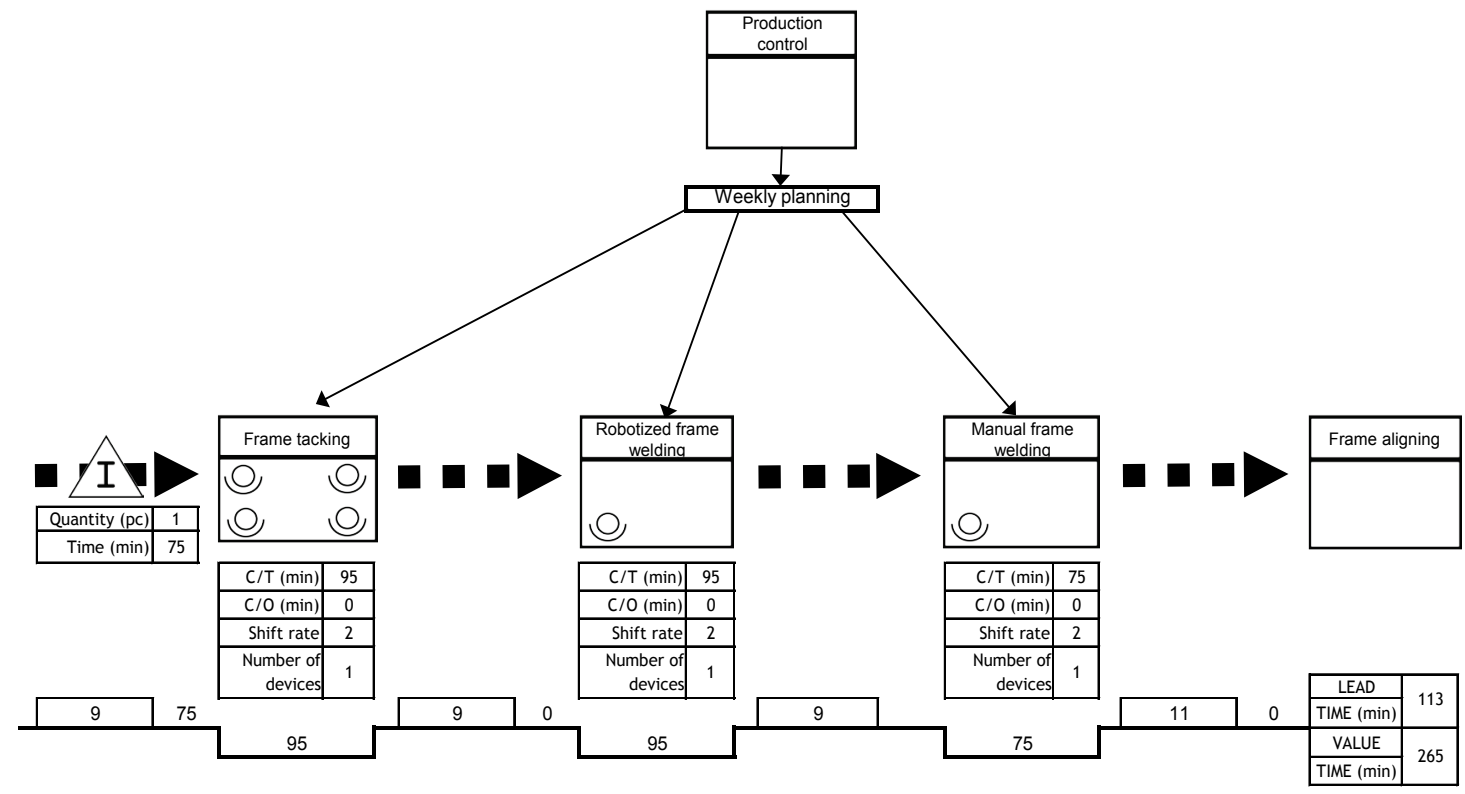

Figure 9 Map of values stream of proposed state

\section{Results}

The main and the most significant benefit rests on economic advantage, maximization of production capacities utilization, and enhancement of throughput and continuity of frame production process. The analysis uncovered the possibility of improvement especially in the material flow sphere making it more effective. Storage places elimination of production in progress which represents the chief source of lost time occurrence should result in more continuous material flow through the production process.

Fusion of operations shown in Fig. 5 should allow space vacating for extension of robotized welding of the entire frame by four robots. This step should enable to lay out the production so that in the course of the same available time period it is possible to produce two more semitrailer frames (Fig. 10). The RZP extension should cause disengagement of the robots, i.e. RZP-1 which should be able to perform other welding activities. The workplace reorganization hides also a possibility of a robotized formation cell for welding of the selected frame type by means of which more optimal utilization of space capacities of the company could be achieved. At the same time the changes would cause decrease in need of workers at the workplace who could thus perform other activities.

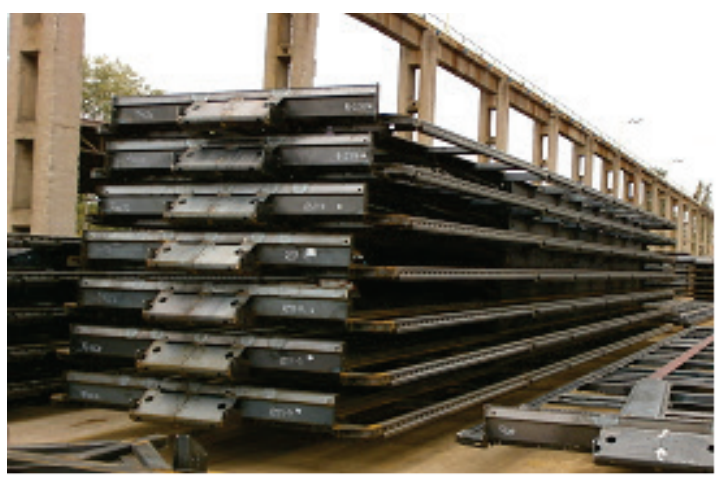

Figure 10 Shipping department with welded frames
Tab. 1 presents comparison of values of the key metrics of the current and of the proposed state. The numerical expression shows that the changes would enhance the individual mapped values which are the proof of the overall benefit of offered improvements.

Table 1 Comparison of values of metrics of current and proposed state

\begin{tabular}{|c|c|c|c|c|c|}
\hline Metrics & $\begin{array}{c}\text { Clock } \\
\text { period } \\
(\mathrm{min})\end{array}$ & $\begin{array}{c}\text { CPP } \\
(\mathrm{min})\end{array}$ & $\% \mathrm{VA}$ & $\begin{array}{c}\mathrm{ST} \\
(\mathrm{x} / \text { year })\end{array}$ & NPS \\
\hline Current & 128,57 & 1433 & 37,19 & 218 & 23 \\
\hline Proposed & 100 & 369 & 71,82 & 937 & 11 \\
\hline
\end{tabular}

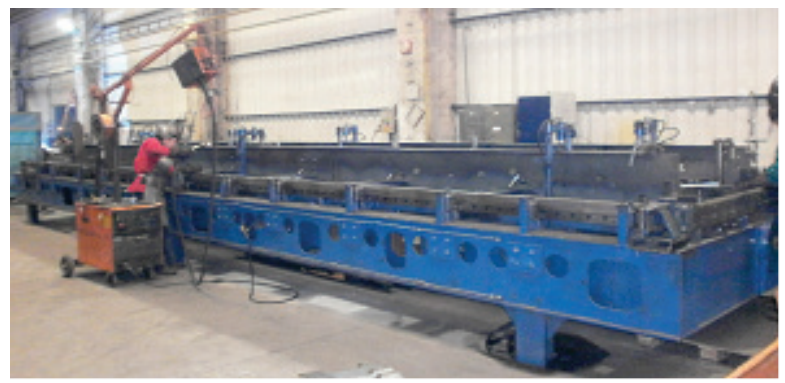

Figure 11 Deck tacking area

\section{Conclusion}

The aim of the paper was to broaden the awareness related to possibilities of continuous improvement in company processes through implementing lean production tools. To realize the aforementioned rationalizing proposals in the TOMARK, Ltd. the following should be inevitable: purchasing new welding and manipulating technology, reorganizing production, fusion of operations and new specification of workplace staffing. Therefore financial part of the issue is important to be emphasized. The main preconditions to perform the aforementioned are sufficient financial means necessary to be invested in the initial project stage. Returnability of investments according to the measured values and on the basis of information provided by the company on labour cost would be as per approximate calculation in 2,45 years which represents 613 working days. The result 
cannot be taken as the decisive one as under the influence of production deviations precise time periods are impossible to be defined. To acquire more exact time periods the monitoring of the process in the course of a long-term timeline would be inevitable.

With the proposed implementation of manipulation equipment utilization at a workplace, the returnability of investment can be expressed just in time range of financial savings related to manipulation, which is approximately 4509 of saved minutes in case of manipulation.

According to these results and comparison of values of metrics in Tab. 1 the meaningfulness of implementation of elements of lean thinking into the process of the selected operation part can be confirmed. By means of gradual leaning of the production program the company should solidify reputation at the market and could represent good motivation for other companies hesitating to introduce the utilization of enhancement system by lean production concepts.

\section{Nomenclature}

$\% V A$ - index of added value, $\%$

$A D C$ - annual demand of a customer, pc

$C P P$ - continuous production period, $\min$

$D D C$ - daily demand of a customer, $\mathrm{pc}$

$N P S$ - number of procedural steps, -

$N V A$ - activities not adding the value, min

$P S N V A$ - partial procedural steps without added value, -

$P S V A$ - partial procedural steps with added value, -

$P S V E$ - partial procedural steps allowing the value formation, -

$S T$ - stock turn, times/yr

$V A$ - activities adding the value, min

$V E$ - activities allowing the value formation, min.

\section{Acknowledgment}

The study was supported by: Scientific Grant Agency within the framework of the project VEGA 1/4157/07.

\section{References}

[1] Womack, J.; Jones, D. Machine that change the world. Macmillan Publishing, New York. 1990.

[2] Košturiak, J.; Frolík, Z. Lean and Innovative Enterprise. Alfa Publishing, Praha, 2006.

[3] Rother, M.; Shook, M. Learning to See - value stream mapping to create value and eliminate muda. Lean Enterprise Institute, Cambridge, 1997.

[4] Božičkovič, R.; Radošević, M.; Ćosić, I.; Soković, M.; Rikalović, A. Integration of Simulation and Lean Tools in Effective Production Systems - Case Study. // Strojniški vesnik - Journal of Mechanical Engineering. 58, 11(2012), pp. 642-652. DOI: 10.5545/sv-jme.2012.387

[5] Arsovski, S.; Arsovski, Z.; Mirovic, Z. The integration role of simulation in modern manufacturing planning and scheduling. // Strojniški vestnik - Journal of Mechanical Engineering. 55, 1(2009), pp. 33-44.

[6] Abdulmalek, F.; Rajgopal, J. Analyzing the benefits of lean manufacturing and value stream mapping via simulation: A process sector case study. // International Journal of Production Economics. 107, 1(2007), pp. 223-236. DOI: 10.1016/j.ijpe.2006.09.009
[7] Chen, J. C.; Li, Y.; Shady, B. D. From value stream mapping toward a lean/sigma continuous improvement process: an industrial case study. // International Journal of Production Research. 48, 4(2010), pp. 1069-1086. DOI: 10.1080/00207540802484911

[8] Gjeldum, N.; Veža, I.; Bilić, B. Simulation of production process reorganized with value stream mapping. // Tehnički Vjesnik - Technical Gazette. 18, 3(2011), pp. 341-347.

[9] Harris, R.; Harris, Ch.; Wilson, E. Making Materials Flow, Cambridge, MA: Lean Enterprise Institute, 2003.

[10] Kysel', M. Mapovanie toku hodnôt vo výrobe, Fraunhofer IPA Slovakia, Žilina, 2010. (in Slovak)

[11] Smalley, A. Creating Level Pull: Foreword, Slovak Productivity Centre, Žilina, 2009.

[12] TOMARK, s.r.o. URL: http://www.tomark.sk/en/home (01.03.2013).

[13] Rimský, F. Optimalization of technological process welding. Diploma thesis. Technical University of Košice, Faculty of Manufacturing Technologies, Prešov, 2011.

[14] Kanáliková, E. Identification of hidden reserves in the company with Value Stream Mapping. / Diploma thesis. Technical University of Košice, Faculty of Manufacturing Technologies, Prešov, 2012

[15] OTC Daihen Inc. Arc Welding Robots, URL: http://www.mac-tech.com/literature/otc/AXV4L_CAT_NO_A456.pdf (20.09.2012).

[16] Królczyk, G.; Legutko, S.; Królczyk, J.; Tama, E. Materials flow analysis in the production process - case study. // Applied Mechanics and Materials. 474 (2014) pp. 97-102. DOI: 10.4028/www.scientific.net/AMM.474.97

[17] Krolczyk, G.; Królczyk, J.; Legutko, S.; Hunjet, A. Effect of the disc processing technology on the vibration level of the chipper during operations process. // Tehnički Vjesnik Technical Gazette. 21, 2 (2014), pp. 447-450.

[18] Radvanska, A. et al. Rationalization of manufacturing of plastics injection moulds by abrasive water jet. // Tehnički Vjesnik - Technical Gazette. 22, 2(2015), pp. 521-525. DOI: 10.17559/TV-20130502125348

\section{Authors' addresses}

\section{Dominika Lehocká}

Faculty of Manufacturing Technologies of Technical Universtity of Košice with a seat in Prešov, Bayerova 1,080 01 Prešov, Slovak Republic

lehocka.dominika@gmail.com

\section{Ivo Hlavatý}

Faculty of Mechanical Engineering,

VŠB - Technical University of Ostrava

17. listopadu $15 / 2172$,

70833 Ostrava-Poruba, Czech Republic

\section{Sergej Hloch}

Faculty of Manufacturing Technologies of Technical Universtity of Košice with a seat in Prešov, Bayerova 1, 08001 Prešov, Slovak Republic 